\title{
PRZYJĘCIE I ODMOWA PRZYJĘCIA DO PAŃSTWOWEGO ZASOBU GEODEZYJNEGO I KARTOGRAFICZNEGO WYNIKÓW ZGŁOSZONYCH PRAC GEODEZYJNYCH - WYBRANE ZAGADNIENIA
}

\begin{abstract}
Abstrakt: Artykuł 12b ustawy z dnia 17 maja 1989 roku — Prawo geodezyjne i kartograficzne reguluje procedurę przyjęcia wyników prac geodezyjnych do państwowego zasobu geodezyjnego i kartograficznego. Jej efektem może być przyjęcie opracowań do zasobu w formie czynności materialno-technicznej lub odmowa przyjęcia wyników prac do zasobu w formie decyzji administracyjnej. Taka konstrukcja normatywna wywołuje liczne problemy w praktyce stosowania prawa, związane między innymi z dopuszczalnością stosowania przepisów k.p.a., wszczęciem postępowania administracyjnego, przedmiotem sprawy administracyjnej czy też rodzajami rozstrzygnięć organu odwoławczego. Autor podejmuje próbę odpowiedzi na zasadnicze pytania, z którymi na co dzień muszą mierzyć się organy Służby Geodezyjnej i Kartograficznej.
\end{abstract}

Słowa kluczowe: weryfikacja prac geodezyjnych i kartograficznych, protokół weryfikacji, postępowanie administracyjne, czynności materialno-techniczne, decyzja administracyjna

Dnia 12 lipca 2014 roku $^{1}$ do ustawy z dnia 17 maja 1989 roku — Prawo geodezyjne i kartograficzne ${ }^{2}$ dodano art. $12 \mathrm{~b}$ regulujący tryb postępowania w sprawie przyjęcia do państwowego zasobu geodezyjnego i kartograficznego wyników zgłoszonych prac geodezyjnych. Jego ostatnia (szósta już z kolei) nowelizacja ${ }^{3}$, która weszła w życie 31 lipca 2020 roku, nadała aktualny kształt normatywny instytucji prawnej, którą statuuje rzeczony przepis. Wydaje się, że miało to być remedium na liczne problemy, które ujawniały się w działalności organów Służby Geodezyjnej

${ }^{1}$ Dzień wejścia w życie ustawy z dnia 5 czerwca 2014 roku o zmianie ustawy — Prawo geodezyjne i kartograficzne oraz ustawy o postępowaniu egzekucyjnym w administracji, Dz.U. z 2014 r. poz. 897.

2 Dz.U. z 2020 r. poz. 276 ze zm. (dalej: p.g.k.).

3 Nowelizacji dokonano ustawą z dnia 16 kwietnia 2020 roku o zmianie ustawy - Prawo geodezyjne i kartograficzne oraz niektórych innych ustaw, Dz.U. z 2020 r. poz. 782. 
i Kartograficznej przy okazji jego stosowania, których dowodem istnienia jest stosunkowo bogate orzecznictwo sądów administracyjnych zapadłe na jego kanwie. Ramy opracowania przesądziły jednak o konieczności okrojenia prowadzonych rozważań do wybranych zagadnień związanych z podjętą tematyką — przede wszystkim tych, które nie zostały dotychczas podjęte w literaturze przedmiotu lub też sposób ich ujęcia daje podstawy do formułowania stanowisk polemicznych.

Ustawodawca nakłada na wykonawcę prac geodezyjnych obowiązek zgłoszenia ich wyników właściwym organom Służby Geodezyjnej i Kartograficznej. Celem przekazania wyników zgłoszonych uprzednio prac jest ich weryfikacja pod względem zgodności z obowiązującymi przepisami prawa z zakresu geodezji i kartografii oraz spójności przekazywanych zbiorów danych, o których mowa $\mathrm{w}$ art. $12 \mathrm{a}$ ust. 1 pkt 1 p.g.k., z prowadzonymi przez ten organ bazami danych. Organy zobligowane są dokonać weryfikacji niezwłocznie, w wypadku zaś prac, o których mowa $\mathrm{w}$ art. 12 ust. 1 pkt 3 p.g.k., termin ten zależny jest od powierzchni obszaru objętego zgłoszeniem prac: (do 1 ha — nie później niż w terminie siedmiu dni roboczych; powyżej 1 ha do 10 ha — nie później niż w terminie dziesięciu dni roboczych; powyżej 10 ha — nie później niż w terminie dwudziestu dni roboczych od dnia otrzymania przez organ Służby Geodezyjnej i Kartograficznej zawiadomienia o przekazaniu wyników zgłoszonych prac).

Wynik weryfikacji (pozytywny albo negatywny) uwzględniony zostaje w protokole, o czym informuje się wykonawcę za pomocą środków komunikacji elektronicznej nie później niż w dniu roboczym następującym po dniu jego sporządzenia. Dalsze czynności organu zależne są od rezultatu weryfikacji. Jeśli ten jest pozytywny, organ przyjmuje wyniki zgłoszonych prac do państwowego zasobu geodezyjnego i kartograficznego w drodze czynności materialno-technicznej ${ }^{4}$. Negatywny wynik weryfikacji oznacza konieczność zwrotu wykonawcy prac geodezyjnych, przekazanych przez niego wyników zgłoszonych prac oraz doręczenia mu protokołu weryfikacji, zawierającego opis stwierdzonych uchybień i nieprawidłowości. Wymaga się, aby był on przedstawiony w sposób jasny, czytelny i zrozumiały, przede wszystkim zaś powinien wskazywać konkretne przyczyny uzasadniające zwrot dokumentacji, aby umożliwić wykonawcy rzeczowe ustosunkowanie się do przedstawionych zarzutów i dać szansę na usunięcie stwierdzonych nieprawidłowości ${ }^{5}$. Od tego momentu przebieg postępowania zależny jest od stanowiska zajętego przez wykonawcę. Ma on prawo ustosunkować się na piśmie do wyników weryfikacji w terminie czternastu dni od dnia otrzymania protokołu. Zwrot, o którym mowa, powinien zatem nastąpić w sposób umożliwiający organowi ustalenie jego daty ${ }^{6}$.

${ }^{4}$ Wyrok Wojewódzkiego Sądu Administracyjnego w Kielcach z dnia 18 października 2018 r., II SA/Ke 566/18, LEX nr 2576813.

5 Wyrok Wojewódzkiego Sądu Administracyjnego w Gdańsku z dnia 20 kwietnia 2017 r., III SA/Gd 156/17, LEX nr 2285870.

${ }^{6}$ Wyrok Wojewódzkiego Sądu Administracyjnego w Krakowie z dnia 28 listopada 2019 r., III SA/Kr 987/19, LEX nr 2764722. 
W wypadku uznania wadliwości stwierdzonych w protokole wykonawca, w terminie trzech miesięcy od dnia otrzymania protokołu, przekazuje do organu Służby Geodezyjnej i Kartograficznej poprawione wyniki zgłoszonych prac geodezyjnych wraz z zawiadomieniem o ich przekazaniu. Jeżeli odpowiadają one wymogom prawnym, organ wydaje kolejny protokół, tym razem z pozytywną weryfikacją. Żaden przepis nie daje podstawy do przyjęcia danych i materiałów do zasobu, które w jakimkolwiek aspekcie pozostają w kolizji z obowiązującymi w geodezji i kartografii przepisami prawa, a to może być stwierdzone wyłącznie w protokole ${ }^{7}$.

Bezskuteczny upływ trzymiesięcznego terminu skutkuje uznaniem prac za zaniechane. W tej sytuacji ponowne podjęcie zaniechanych prac wymaga dokonania nowego zgłoszenia. Wskazany termin może zostać jednak przywrócony. Stosuje się tu przepisy art. 58 oraz 59 ustawy z dnia 14 czerwca 1960 roku - Kodeks postępowania administracyjnego ${ }^{8}$. Ustawodawca wzbogaca jednak kodeksowe przesłanki przywrócenia terminu przyjmując, że jest ono dopuszczalne jedynie w „szczególnie uzasadnionych przypadkach”.

Jeżeli wykonawca negatywnie ustosunkuje się do sporządzonego przez organ protokołu weryfikacji, a organ nie uwzględni stanowiska wykonawcy, wydaje decyzję administracyjną o odmowie przyjęcia do państwowego zasobu geodezyjnego i kartograficznego wyników zgłoszonych prac geodezyjnych, której podstawę prawną stanowi norma art. $12 \mathrm{~b}$ ust. 8 p.g.k.

Jak widać, postępowanie w przedmiocie przyjęcia wyników prac geodezyjnych do państwowego zasobu geodezyjnego i kartograficznego może zakończyć się na trzy sposoby:

1. przyjęciem wyników prac geodezyjnych do zasobu w drodze czynności materialno-technicznej, gdy wyniki prac zostały pozytywnie zweryfikowane w protokole organu Służby Geodezyjnej i Kartograficznej;

2. decyzją administracyjną o odmowie przyjęcia do zasobu wyników prac geodezyjnych w sytuacji, gdy wykonawca w terminie czternastu dni od dnia otrzymania negatywnego protokołu weryfikacji, ustosunkuje się pisemnie do jej wyników, organ zaś nie uwzględni stanowiska wykonawcy;

3. nieprzyjęciem wyników prac geodezyjnych do zasobu w przypadku wydania negatywnego protokołu weryfikacji i braku pisemnego stanowiska wykonawcy w tym zakresie albo przedstawienia tego stanowiska po upływie ustawowego, czternastodniowego terminu9.

Problemów praktycznych nie sprawia zasadniczo pierwsza sytuacja. Regulacja normatywna dotycząca dwóch pozostałych, wywołuje wątpliwości interpretacyjne. Zwrócić należy uwagę na zróżnicowanie formy prawnej rozstrzygnięcia

7 G. Lang, [w:] Prawo geodezyjne i kartograficzne. Komentarz, red. J. Lang et al., Warszawa 2018, s. 211-212.

8 Dz.U. z 2020 r. poz. 256.

9 Wyrok Wojewódzkiego Sądu Administracyjnego w Gorzowie Wielkopolskim z dnia 25 maja 2017 r., II SA/Go 221/17, LEX nr 2299581. 
organu w zależności od rezultatu postępowania w przedmiocie przyjęcia wyników prac geodezyjnych do państwowego zasobu geodezyjnego i kartograficznego. Rozstrzygnięcie pozytywne dla wykonawcy następuje w formie czynności materialno-technicznej, forma zaś decyzji administracyjnej dotyczy sytuacji, w której organ odmawia przyjęcia wyników zgłoszonych prac do zasobu. Przyjęta konstrukcja jest przykładem coraz częściej spotykanych w regulacjach administracyjnego prawa materialnego rozwiązań, w których autorytatywna konkretyzacja normy prawnej w zakresie uprawnień jednostki jest wynikiem czynności materialnoprawnej jednostki, a władztwo administracyjne organu jest ograniczone do kontroli zgodności z prawem tejże czynności. Ocena czynności jednostki następuje poza postępowaniem administracyjnym, choć jej wynik może skutkować podjęciem decyzji administracyjnej ${ }^{10}$.

Za nietrafne należy uznać stanowisko Wojewódzkiego Sądu Administracyjnego w Krakowie, wyrażone w uzasadnieniu wyroku z 15 października 2019 roku $^{11}$, jakoby regulacja postępowania dotyczącego przyjęcia zbiorów danych i innych materiałów do zasobu geodezyjnego i kartograficznego, zawarta w art. 12 b p.g.k., wyłączała zastosowanie przepisów k.p.a. Pogląd ten jest wadliwy, bowiem procedura uregulowana $\mathrm{w}$ art. $12 \mathrm{~b}$ ust. 1 pkt 1-7 p.g.k. w żaden sposób nie została objęta zakresem mocy obowiązującej kodeksu. Zgodnie z art. 1 pkt 1 k.p.a. normuje on ,postępowanie przed organami administracji publicznej w należących do właściwości tych organów sprawach indywidualnych, rozstrzyganych w drodze decyzji administracyjnych albo załatwianych milcząco". Przepis ten wymaga dla zastosowania regulacji kodeksowej kumulatywnej realizacji czterech warunków: 1. postępowanie w sprawie będzie prowadzić organ administracji publicznej; 2. sprawa pozostaje we właściwości tego organu; 3. sprawa ma charakter indywidualny; 4. przepisy dają podstawę do rozstrzygnięcia sprawy poprzez wydanie decyzji administracyjnej ${ }^{12}$.

Choć sprawa przyjęcia wyników prac geodezyjnych do zasobu jest procedowana przed organem administracji publicznej, należy do jego właściwości oraz ma charakter sprawy indywidualnej, to dla jej rozstrzygnięcia nie zastrzeżono formy decyzji administracyjnej. Jak już wskazano, forma ta jest przewidziana wyłącznie na wypadek odmowy przyjęcia wyników prac do zasobu w konsekwencji nieuwzględnienia przez organ stanowiska wykonawcy, wniesionego wobec protokołu weryfikacji. Zatem tylko w tej szczególnej sytuacji mamy do czynienia z postępowaniem administracyjnym, o którym mowa w k.p.a. W tym postępowaniu

10 Zob. B. Adamiak, Czynności prawne jednostki a władztwo administracyjne, [w:] Wspótczesne zagadnienia prawa i procedury administracyjnej. Księga jubileuszowa dedykowana Prof. zw. dr. hab. Jackowi M. Langowi, red. J. Jagielski et al., Warszawa 2009, s. 23-35.

11 Wyrok Wojewódzkiego Sądu Administracyjnego w Krakowie z dnia 15 października 2019 r., III SA/Kr 862/19, LEX nr 2734269.

12 J. Borkowski (aktualizacja B. Adamiak), [w:] Postępowanie administracyjne i sqadowoadministracyjne, red. B. Adamiak, J. Borkowski, Warszawa 2020, s. 120-121. 
regulacje kodeksowe stosowane są — wbrew twierdzeniom sądu - w pełnym zakresie, bowiem art. 12b ust. 1-7c p.g.k. swą regulacją obejmuje czynności poprzedzające wszczęcie postępowania administracyjnego ${ }^{13}$, a art. $12 \mathrm{~b}$ ust. 8 p.g.k. jest przepisem prawa materialnego stanowiącym podstawę rozstrzygnięcia. Przepisów tych w żadnym razie nie można zatem traktować $\mathrm{w}$ charakterze lex specialis w stosunku do regulacji kodeksowej.

Uznanie, że odmowa przyjęcia prac do zasobu następuje w formie decyzji administracyjnej wydawanej w postępowaniu administracyjnym, niesie z sobą konieczność przesądzenia kilku kluczowych kwestii. Pierwszą z nich jest data wszczęcia postępowania, o którym mowa. W orzecznictwie przyjmuje się, że wszczęcie rzeczonego postępowania następuje na zasadzie oficjalności (,z urzędu”) ${ }^{14}$. Warunkiem sine qua non wszczęcia postępowania jest przedłożenie przez wykonawcę, w ustawowym terminie, negatywnego stanowiska wobec otrzymanego protokołu weryfikacji. Jako sporna jawi się okoliczność uzależnienia wszczęcia postępowania od zachowania przez wykonawcę pisemnej formy ustosunkowania się do protokołu weryfikacji. Zasadniczo uznaje się, że nieprzedłożenie w wyznaczonym terminie pisemnego stanowiska przez wykonawcę skutkuje nieprzyjęciem wyników prac geodezyjnych do zasobu, bez wydawania w tym zakresie jakiejkolwiek decyzji. Decyzja administracyjna jest wydawana wówczas, gdy wykonawca ustosunkował się na piśmie do wyników weryfikacji, zaś organ nie uwzględnił tego stanowiska. Pisemne ustosunkowanie się wykonawcy do stwierdzonych protokołem braków i nieprawidłowości w przekazanych przez niego opracowaniach jest warunkiem dalszego procedowania organu w sprawie, jak również wydania decyzji o odmowie przyjęcia do zasobu opracowań wykonawcy ${ }^{15}$. Zgodnie z innym zapatrywaniem za co najmniej dyskusyjne należy uznać uzależnianie wydania decyzji, o której mowa w art. $12 \mathrm{~b}$ ust. 8 p.g.k., od pisemnego ustosunkowania się do wyników weryfikacji. Wskazany przepis takiego warunku nie zawiera, nie jest sformułowany na przykład: ,jeżeli organ nie uwzględni pisemnego stanowiska wykonawcy" lub ,jeżeli organ nie uwzględni stanowiska wykonawcy wyrażonego na piśmie”, a stanowi jedynie o nieuwzględnieniu „stanowiska wykonawcy”. Oznacza to, że stanowisko wykonawcy może być wyrażone w dowolnej formie, $\mathrm{w}$ tym w formie ponownego przesłania zbiorów danych lub innych materiałów, czy też częściowego ich uzupełnienia ${ }^{16}$.

13 Na temat znaczenia pojęcia „postępowanie administracyjne” zob. B. Adamiak, Pojęcie postępowania administracyjnego, [w:] Kodyfikacja postępowania administracyjnego: na 50-lecie K.P.A., red. J. Niczyporuk, Lublin 2010, s. 15-21.

14 Tak wyrok Naczelnego Sądu Administracyjnego z dnia 16 lipca 2020 r., I OSK 2982/19, LEX nr 3064825.

15 Wyrok Wojewódzkiego Sądu Administracyjnego w Kielcach z dnia 18 października 2018 r., II SA/Ke 566/18, LEX nr 2576813.

16 Wyrok Wojewódzkiego Sądu Administracyjnego w Krakowie z dnia 15 października 2019 r., III SA/Kr 862/19, LEX nr 2734269. 
Trudno zgodzić się z drugim z zaprezentowanych stanowisk. Normę art. 12b ust. 8 p.g.k. należy wykładać w kontekście całościowej regulacji art. 12b p.g.k. W ust. 7 ustawodawca wyraźnie wskazuje na pisemną formę stanowiska wykonawcy, w ust. 8 zaś odnosi się do nieuwzględnienia tego stanowiska.

Uzależnienie dopuszczalności wszczęcia postępowania administracyjnego w sprawie przyjęcia wyników prac geodezyjnych do zasobu od przedłożenia pisemnego stanowiska wykonawcy w ustawowym terminie skutkuje uznaniem, że stanowisko wykonawcy do wyników weryfikacji przedłożone organowi $\mathrm{z}$ uchybieniem terminu skutkuje koniecznością wydania postanowienia o odmowie wszczęcia postępowania na podstawie art. $61 \mathrm{a} \S 1$ k.p.a. Odmowa wszczęcia postępowania nastąpi także, gdy wykonawca prac w terminie czternastu dni od doręczenia mu negatywnego protokołu weryfikacji ponownie złoży swoje opracowanie, bez usunięcia stwierdzonych braków i nieprawidłowości ${ }^{17}$.

Organ powinien poinformować stronę o wszczęciu postępowania administracyjnego dopiero wówczas, gdy po złożeniu przez wykonawcę pisemnego stanowiska, przebieg postępowania orientuje się na wydanie decyzji administracyjnej ${ }^{18}$. Nadmienić przy tym należy, że choć przepisy k.p.a. nie regulują daty wszczęcia postępowania z urzędu, to w orzecznictwie przyjmuje się, że ,za datę taką można uznać dzień pierwszej czynności urzędowej dokonanej w sprawie, której postępowanie dotyczy, przez organ do tego uprawniony, działający w granicach przysługujących mu kompetencji, pod warunkiem, że o czynności tej powiadomiono stronę"19. Pierwszą czynnością jest zawiadomienie o wszczęciu postępowania (art. $61 \S 4$ k.p.a. $)^{20}$. Ustalenie daty wszczęcia postępowania jest istotne z punktu widzenia rozpoczęcia biegu terminu załatwienia sprawy. Jak wskazał Naczelny Sąd Administracyjny w wyroku z dnia 22 lutego 2019 roku $^{21}$, termin do wydania decyzji, o której mowa w art. $12 \mathrm{~b}$ ust. 8 p.g.k., biegnie od dnia przekazania organowi stanowiska wykonawcy do weryfikacji dokumentów geodezyjnych.

Uznanie za zasadne takiego poglądu świadczyłoby o osobliwości tegoż postępowania, bowiem jego wszczęcie następowałoby (wbrew ogólnej regule) nie z momentem doręczenia stronie zawiadomienia o wszczęciu, lecz — jak wskazano - z momentem przedłożenia organowi stanowiska wykonawcy, co przypomina regułę wynikającą z treści art. $61 \S 3$ k.p.a., który za datę wszczęcia postępowania administracyjnego uznaje dzień doręczenia żądania organowi administracji pu-

17 Wyrok Wojewódzkiego Sądu Administracyjnego w Gorzowie Wielkopolskim z dnia 25 maja 2017 r., II SA/Go 221/17, LEX nr 2299581.

18 Wyrok Wojewódzkiego Sądu Administracyjnego w Kielcach z dnia 18 października 2018 r., II SA/Ke 566/18, LEX nr 2576813.

19 Postanowienie Naczelnego Sądu Administracyjnego w Warszawie z dnia 4 marca 1981 r., SA 654/81, LEX nr 9607.

20 B. Adamiak, [w:] Kodeks postępowania administracyjnego. Komentarz, red. B. Adamiak, J. Borkowski, Warszawa 2017, s. 378.

${ }^{21}$ I OSK 434/17, LEX nr 2653600. 
blicznej. Przepis ten odnosi się jednakże wyłącznie do postępowań wszczynanych na zasadzie skargowości.

Choć wskazane stanowisko Naczelnego Sądu Administracyjnego chroni interesy wykonawcy, skracając przewidziany dla organu termin załatwienia sprawy, to wydaje się, że nie znajduje ono podstaw normatywnych. Jego akceptacja oznaczałaby, że od doręczenia organowi stanowiska wykonawcy toczy się postępowanie administracyjne. Tymczasem należy zauważyć, że organ może uznać stanowisko wykonawcy i przyjąć materiały do zasobu w formie czynności materialno-technicznej, która nie jest przecież podejmowana w postępowaniu administracyjnym. Czynności organu nakierowane na weryfikację prawidłowości stanowiska wykonawcy, w zależności od ich rezultatu, musiałyby być uznawane raz za podejmowane w toku postępowania administracyjnego (gdy ich efektem będzie nieuznanie stanowiska wykonawcy), innym razem za dokonywane poza ramami postępowania administracyjnego (wówczas gdy organ, uwzględniając stanowisko wykonawcy, zdecyduje o przyjęciu materiałów do zasobu).

Kolejnym stadium postępowania administracyjnego jest ustalenie stanu faktycznego na potrzeby rozstrzygnięcia sprawy. Rozeznanie zakresu postępowania wyjaśniającego ma podstawowe znaczenie dla oceny dochowania przez organ wymogów wynikających z zasady prawdy obiektywnej (art. 7 in media k.p.a.). O zakresie postępowania dowodowego przesądza norma prawa materialnego, której autorytatywna konkretyzacja jest przedmiotem postępowania administracyjnego. Przesłanką wydania decyzji o odmowie przyjęcia wyników prac geodezyjnych do zasobu jest nieuwzględnienie przez organ stanowiska wykonawcy prac geodezyjnych wobec negatywnego protokołu weryfikacji (art. 12b ust. 8 p.g.k.). Choć mogłoby się z pozoru wydawać, że akceptacja przez organ stanowiska wykonawcy wobec protokołu tworzy każdorazowo przeszkodę w wydaniu decyzji o odmowie przyjęcia wyników prac geodezyjnych do zasobu, tak nie jest. Postępowanie wyjaśniające nie może ograniczać się wyłącznie do oceny zasadności zastrzeżeń wykonawcy względem protokołu, lecz do całości przedłożonej przez stronę postępowania dokumentacji geodezyjnej22. Przesądza to o konieczności rozważenia przez organ, czy nie zachodzą inne niż zawarte w protokole weryfikacji uchybienia, które - choć powinny - nie znalazły się w tym protokole. W związku z tym za nietrafny należy uznać pogląd D. Felcenlobena, jakoby granice postępowania administracyjnego, wszczętego w trybie art. $12 \mathrm{~b}$ ust. 8 p.g.k., wyznaczała treść negatywnego protokołu weryfikacji, jak również uzgodnień w tym zakresie dokonanych z wykonawcą prac, $w$ trybie art. $12 \mathrm{~b}$ ust. 7 p.g.k. ${ }^{23}$ Przedmiotem postępowania administracyjnego nie jest kontrola zasadności ujętych w protokole,

22 Wyrok Wojewódzkiego Sądu Administracyjnego w Szczecinie z dnia 12 stycznia 2017 r., II SA/Sz 1179/16, LEX nr 2201962; wyrok Wojewódzkiego Sądu Administracyjnego w Szczecinie z dnia 2 lutego 2017 r., II SA/Sz 1178/16, LEX nr 2240795.

23 D. Felcenloben, Weryfikacja prac geodezyjnych i kartograficznych, „Samorząd Terytorialny" 2017, nr 1-2, s. 153. 
a podważanych przez wykonawcę uchybień i nieprawidłowości, jakimi zdaniem organu mają być obarczone wykonane prace, lecz ocena dopuszczalności przyjęcia ich wyników do zasobu ${ }^{24}$.

W orzecznictwie nie ma jednolitości, gdy idzie o wyznaczenie konsekwencji prawnych uznania wyników prac geodezyjnych za wadliwe z innych przyczyn niż dostrzeżone $\mathrm{w}$ sporządzonym na etapie przedprocesowym protokole weryfikacji. Spotkać można stanowisko, zgodnie z którym treść protokołu weryfikacji ma dla wykonawcy prac geodezyjnych charakter gwarancyjny. Tylko w zakresie wyartykułowanych w jego treści nieprawidłowości, wykonawca prac geodezyjnych ma prawo ustosunkować się do wyników weryfikacji. Dostrzeżenie w toku postępowania nowych wadliwości, nakłada na organy służby geodezyjnej i kartograficznej obowiązek ponowienia weryfikacji, a zatem sporządzenia kolejnego protokołu weryfikacji, którego treść obejmowałaby niedostrzeżone wcześniej wadliwości. Obowiązkiem organu jest zapewnienie wykonawcy prac możliwości odniesienia się do nowych wyników procedury weryfikacyjnej ${ }^{25}$. Przyczyną odmowy przyjęcia wyników prac geodezyjnych do zasobu nie mogą być takie wadliwości tych prac, wobec których strona nie może wyrazić swojego stanowiska w trybie art. 12b ust. 7 p.g.k. ${ }^{26}$ Jak widać, przytoczony pogląd przewiduje obowiązek ponowienia weryfikacji nawet wówczas, gdy organ $\mathrm{z}$ urzędu poweźmie zastrzeżenia co do prawidłowości zgłoszonych prac, które nie zostały ujęte w protokole.

Stanowisko to nie jest akceptowane bez zastrzeżeń. W niektórych judykatach odmawia się organowi prawa do ponownej weryfikacji wyników prac, nawet po otrzymaniu pisemnego stanowiska wykonawcy. Ocena przedstawionych przez wykonawcę argumentów ma bowiem następować w uzasadnieniu decyzji, o której mowa w art. $12 \mathrm{~b}$ ust. 8 p.g.k. Powtórna weryfikacja ma być możliwa, jedynie gdy wykonawca przekaże nowe, uzupełnione dane lub materiały będące wynikami prac geodezyjnych. Wykonawca może wszakże ustosunkować się do protokołu negatywnej weryfikacji jego prac, a w ramach tego może skorygować przedłożony operat. Ich weryfikacja nie jest wówczas ,powtórną”, lecz pierwszą ${ }^{27}$. W przeciwnym razie uznanie, że przedłożone materiały nadal zawierają błędy, obliguje organ do wydania negatywnej decyzji w zakresie przyjęcia danych do zasobu. Brak w ustawie podstaw ku temu, aby przyznać organowi kompetencję do wielokrotnej weryfikacji aż do czasu, gdy przedkładane dane i materiały będą spełniać wszystkie wymogi konieczne do przyjęcia ich do zasobu. Takie działania należy

${ }^{24}$ Wyrok Wojewódzkiego Sądu Administracyjnego w Szczecinie z dnia 13 września 2018 r., II SA/Sz 484/18.

25 Tak wyrok Wojewódzkiego Sądu Administracyjnego w Lublinie z dnia 6 lutego 2020 r., III SA/Lu 366/19, LEX nr 2848023.

${ }^{26}$ Wyrok Wojewódzkiego Sądu Administracyjnego w Kielcach z dnia 18 października 2018 r., II SA/Ke 566/18, LEX nr 2576813.

27 Wyrok Wojewódzkiego Sądu Administracyjnego w Krakowie z dnia 25 kwietnia 2018 r., II SA/Ke 207/18, LEX nr 2500655. 
traktować jako uchylanie się od ustawowego obowiązku wydania decyzji ${ }^{28}$. Dodatkowo, wielokrotne kierowanie do wykonawców prac geodezyjnych negatywnych protokołów weryfikacji dotyczących tej samej pracy, może być postrzegane jako mające na celu uniknięcie przez organ merytorycznej kontroli jego stanowi$\mathrm{ska}^{29}$. Za takim poglądem (zdaniem jego zwolenników) ma przemawiać nie tylko wykładania językowa omawianych przepisów, lecz także wykładnia funkcjonalna - celem wprowadzonej regulacji ma być bowiem umożliwienie wykonawcy zainicjowania jurysdykcyjnego postępowania administracyjnego, a następnie postępowania sądowoadministracyjnego, zmierzających do zbadania legalności stanowiska organu orzekającego $\mathrm{w}$ pierwszej instancji. Ponadto przyjęcie odmiennego zapatrywania ma pozostawać $\mathrm{w}$ sprzeczności nie tylko z zasadą szybkości postępowania, lecz także prawidłami logiki ${ }^{30}$.

Troska o interesy wykonawcy oraz prawidłowość danych zasobu przemawia za akceptacją pierwszego z zaprezentowanych stanowisk. Zgodzić należy się w pełni ze stwierdzeniem, że przepisy art. $12 \mathrm{~b}$ ust. 1-8 p.g.k. mają charakter gwarancyjny $\mathrm{w}$ zakresie uprawnienia wykonawcy prac geodezyjnych do ustosunkowania się do wyników weryfikacji, niezależnie od etapu postępowania w sprawie przyjęcia wyników zgłoszonych prac do zasobu. Wadliwość protokołu weryfikacyjnego nie może prowadzić ani do przyjęcia do zasobu wadliwej pracy geodezyjnej, ani też do pozbawienia jej wykonawcy uprawnienia do ustosunkowania się do wyników weryfikacji ${ }^{31}$. Co więcej, wskazana interpretacja odpowiada ustawowej przesłance wydania decyzji opartej na normie art. $12 \mathrm{~b}$ ust. 8 p.g.k. Jest nią nieuwzględnienie stanowiska wykonawcy prac geodezyjnych. Uznanie, że uwzględnienie stanowiska wykonawcy wobec pierwotnego protokołu weryfikacji, przy jednoczesnym dostrzeżeniu przez organ innych wadliwości wykonanych prac, nieujętych w protokole, do których wykonawca nie mógłby się odnieść, miałoby wystarczająco uzasadniać wydanie decyzji o odmowie przyjęcia do zasobu wyników prac geodezyjnych, wydaje się pozostawać w kolizji z brzmieniem normy art. $12 \mathrm{~b}$ ust. 8 p.g.k. Obawa, że powtórna weryfikacja prac godzi $w$ interesy ich wykonawcy, nie wydaje się zasadna. Ten, jeśli nie podziela nowych zastrzeżeń organu, może bez trudu doprowadzić do wydania decyzji przedkładając polemikę z jego stanowiskiem. Jeśli jednak podzieli ocenę organu co do wadliwości przedłożonych wyników prac, ma szansę na ich korektę. Taka interpretacja chroni wykonawcę prac, dając mu możliwość zapobieżenia negatywnemu rozstrzygnięciu

28 Wyrok Naczelnego Sądu Administracyjnego z dnia 22 lutego 2019 r., I OSK 434/17, LEX nr 2653600 .

${ }^{29}$ Wyrok Wojewódzkiego Sądu Administracyjnego w Warszawie z dnia 25 września 2018 r., II SA/Wr 411/18, LEX nr 2571201.

30 Wyrok Wojewódzkiego Sądu Administracyjnego w Lublinie z dnia 24 listopada 2016 r., II SA/Lu 908/16, LEX nr 2231651.

31 Wyrok Naczelnego Sądu Administracyjnego z dnia 16 lipca 2020 r., I OSK 2982/19, LEX nr 3064825 . 
jego sprawy, nie wyłączając jednocześnie możliwości poszukiwania ochrony jego interesów na drodze administracyjnego toku instancji, a następnie sądowoadministracyjnej kontroli decyzji.

Decyzja o odmowie przyjęcia wyników prac do zasobu może zostać poddana kontroli instancyjnej. Z zasady dwuinstancyjności, mającej konstytucyjne (art. 78 Konstytucji RP ${ }^{32}$ ) i ustawowe (art. 15 k.p.a.) umocowanie, wynika prawo jednostki do odwołania od decyzji. Przedmiotem postępowania odwoławczego jest ponowne rozpoznanie i rozstrzygnięcie sprawy rozstrzygniętej decyzją organu pierwszej instancji ${ }^{33}$. Podstawą rozpoznania sprawy jest materiał dowodowy zgromadzony w postępowaniu pierwszoinstancyjnym. Podlega on ocenie organu odwoławczego, zgodnie z zasadą prawdy obiektywnej i swobodnej oceny dowodów. Jeżeli zostanie stwierdzone, że stan faktyczny nie został w pełni ustalony, organ drugiej instancji zobowiązany jest, zgodnie z art. 136 k.p.a., przeprowadzić uzupełniające postępowanie dowodowe ${ }^{34}$.

Organ odwoławczy rozpatrujący odwołanie od decyzji, której materialnoprawną podstawę stanowi art. $12 \mathrm{~b}$ ust. 8 p.g.k., zobowiązany jest rozważyć, czy przedłożone przez wykonawcę wyniki prac spełniają ustawowe kryteria przyjęcia ich do zasobu. W wyroku z dnia 20 kwietnia 2017 roku, Wojewódzki Sąd Administracyjny w Gdańsku trafnie wskazał, że

Organ odwoławczy musi mieć przy tym na uwadze, że postępowanie wyjaśniające prowadzone w ramach postępowania określonego w art. 12 b ust. 1 u.p.g.k. nie może ograniczać się wyłącznie do analizy zarzucanych wykonawcy uchybień i nieprawidłowości stwierdzonych w protokole weryfikacji (który sporządza organ pierwszej instancji). Swym zakresem postępowanie to winno objąć całokształt zgromadzonej dokumentacji a także obejmować zasadność podstaw nieuwzględnienia stanowiska strony względem negatywnego wyniku weryfikacji, gdyż — jak wskazano powyżej — nieuwzględnienie stanowiska strony ustosunkowującej się do negatywnego wyniku weryfikacji jest wyłącznym determinantem decyzji administracyjnej, mającej swą podstawę w art. 12 b ust. 8 u.p.g.k. ${ }^{35}$

Dostrzeżenie w toku postępowania odwoławczego dalszych wadliwości zgłoszonej pracy obliguje organy Służby Geodezyjnej i Kartograficznej do ponowienia weryfikacji, co wiąże się z obowiązkiem sporządzenia kolejnego protokołu weryfikacji obejmującego niedostrzeżone wcześniej wadliwości. Wykonawcy należy zagwarantować prawo odniesienia się do nowych wyników procedury weryfikacyjnej $^{36}$. Przyjmuje się, że możliwość uwzględnienia przez organ odwoławczy

32 Konstytucja Rzeczypospolitej Polskiej z dnia 2 kwietnia 1997 r., Dz.U. Nr 78, poz. 483 ze zm.

33 B. Adamiak, [w:] System Prawa Administracyjnego Procesowego, t. 2, cz. 5. Weryfikacja rozstrzygnięć w postępowaniu administracyjnym ogólnym, red. B. Adamiak, Warszawa 2019, s. 182.

34 B. Adamiak, J. Borkowski, Glosa do wyroku Naczelnego Sadu Administracyjnego - Ośrodek Zamiejscowy we Wroctawiu z dnia 26 sierpnia 1988 r., sygn. akt SA/Wr 773/87, OSP 1990, s. 756.

35 III SA/Gd 156/17, LEX nr 2285870.

36 Wyrok Naczelnego Sądu Administracyjnego z dnia 16 lipca 2020 r., I OSK 2982/19, LEX nr 3064825 . 
dodatkowych uchybień kontrolowanego operatu nie stoi w sprzeczności z zasadą dwuinstancyjności postępowania administracyjnego ${ }^{37}$.

Organ odwoławczy może nie podzielić stanowiska strony postępowania o bezzasadności odmowy przyjęcia wyników prac do zasobu. Przyczyną tego mogą być także te ich wadliwości, które nie zostały wyartykułowane w protokole weryfikacji sporządzonym przez organ pierwszej instancji. Właściwą reakcją organu drugiej instancji jest tu utrzymanie w mocy zaskarżonej decyzji na podstawie art. $138 \S 1$ pkt 1 k.p.a. Problematyczna jest natomiast treść decyzji organu odwoławczego w konsekwencji uznania, że wyniki prac spełniają kryteria przyjęcia ich do zasobu. Źródłem wątpliwości jest fakt, że w art. 12 b p.g.k. ustawodawca różnicuje formę rozstrzygnięcia sprawy w zależności od tego, czy jest ono pozytywne czy negatywne dla wykonawcy. Jak wielokrotnie podkreślano, formę decyzji zastrzeżono dla odmowy przyjęcia wyników prac do zasobu. Okoliczność ta nie stoi czasem na przeszkodzie wywodzeniu, że organ odwoławczy, uwzględniając odwołanie od decyzji, o której mowa w art. 12 b ust. 8 p.g.k., może uchylić zaskarżoną decyzję i rozstrzygnąc sprawę co do jej istoty w oparciu o normę art. $138 \S 1$ pkt 2 k.p.a. ${ }^{38}$ Zdaniem M. Wolanina, choć w art. $12 \mathrm{~b}$ ust. 4 p.g.k. za podstawę do przyjęcia zbiorów danych lub innych materiałów do państwowego zasobu geodezyjnego i kartograficznego uznano pozytywny wynik weryfikacji, to systematyka treści całego art. $12 \mathrm{~b}$ p.g.k. wskazuje, że powołane stwierdzenie dotyczy wyłącznie formy działania organu pierwszej instancji, prowadzącego zasób, gdy już na tym etapie wynik weryfikacji opracowań złożonych przez wykonawcę będzie pozytywny. Dalsza treść omawianego przepisu określa procedurę stosowaną w przypadku negatywnego wyniku weryfikacji opracowań wykonawcy, która kończy się decyzją organu pierwszej instancji, gdy organ ten nie uwzględni pisemnego stanowiska wykonawcy wobec tej weryfikacji. Brakuje zatem, w ocenie autora, dostatecznych podstaw do twierdzenia, jakoby organ odwoławczy nie był uprawniony do zastosowania art. $138 \S 1$ pkt 2 k.p.a. w części dotyczącej uchylenia decyzji organu pierwszej instancji i merytorycznego rozstrzygnięcia przedmiotu sprawy, którym jest ocena dopuszczalności przyjęcia opracowań wykonawcy do zasobu ${ }^{39}$. Przedstawiony pogląd nie wydaje się trafny. Trudno przyjąć, że jedna czynność, jaką jest przyjęcie wyników prac do zasobu, raz przybiera formę czynności materialno-technicznej, innym zaś razem formę decyzji administracyjnej w zależności od etapu postępowania w sprawie przyjęcia materiałów do zasobu, na którym dochodzi do jej podjęcia. Należy zauważyć, że ustawodawca expressis

37 Wyrok Wojewódzkiego Sądu Administracyjnego w Rzeszowie z dnia 13 lutego 2018 r., II SA/Rz 1325/17, LEX nr 2457399.

38 Tak J. Krupiński, Postępowanie w sprawie przyjęcia materiatów do powiatowej części państwowego zasobu geodezyjnego i kartograficznego, cz. III - podmioty postępowania, „Nieruchomości" 2018, nr 4, s. 43; M. Wolanin, Przyjmowanie opracowań do państwowego zasobu geodezyjnego i kartograficznego - refleksje proceduralne, cz. II, „Nieruchomości” 2017, nr 2, s. 37.

39 M. Wolanin, op. cit., s. 40. 
verbis nie wskazuje, że przyjęcie wyników prac geodezyjnych do zasobu następuje w klasycznej formie działania organów administracji, jaką jest decyzja administracyjna. Forma ta jest zastrzeżona dla odmowy przyjęcia prac do zasobu. Artykuł $12 \mathrm{~b}$ p.g.k. przewiduje zatem dwie formy konkretyzacji normy prawa materialnego — czynność materialno-techniczną oraz decyzję administracyjną.

Jednym $\mathrm{z}$ warunków prawidłowości działania organów administracji publicznej jest zachowanie właściwej formy konkretyzacji prawa materialnego ${ }^{40}$. Ustawodawca wprost reguluje konsekwencje prawne rozstrzygnięcia sprawy w formie decyzji, gdy przepisy prawa nie pozwalają na decyzyjną formę rozstrzygnięcia sprawy. Zgodnie z art. $156 \S 1$ pkt 2 k.p.a. organ administracji publicznej stwierdza nieważność decyzji, która wydana została bez podstawy prawnej lub z rażącym naruszeniem prawa. Przyjmuje się, że z wydaniem decyzji bez podstawy prawnej mamy do czynienia wówczas, gdy wydano ją, mimo że wydanie decyzji w danej sprawie nie znajduje uzasadnienia $\mathrm{w}$ przepisach materialnego prawa administracyjnego ${ }^{41}$, na przykład gdy przepisy materialnoprawne przyjmują inną formę działania ${ }^{42}$. W polskim systemie prawnym brakuje podstawy, która upoważniałaby do dokonywania czynności materialno-technicznej decyzją administracyjną ${ }^{43}$.

Przytoczone argumenty zdają się przemawiać przeciwko dopuszczalności podjęcia rozstrzygnięcia merytoryczno-reformatoryjnego w postępowaniu odwoławczym. Właściwą reakcją organu odwoławczego na wypadek uznania, że wyniki prac spełniają kryteria przyjęcia ich do zasobu, jest wydanie decyzji kasatoryjnej typowej, a więc uchylenie zaskarżonej decyzji i umorzenie postępowania pierwszej instancji na podstawie normy art. 138 § 1 pkt 2 k.p.a. Taka treść decyzji jest odpowiednia do ustalenia niedopuszczalności merytorycznego rozstrzygnięcia spraw ${ }^{44}$. W opisanej sytuacji $\mathrm{w}$ istocie $\mathrm{z}$ taką niedopuszczalnością mamy do czynienia, albowiem na przeszkodzie wydaniu rozstrzygnięcia merytorycznego o odmowie przyjęcia wyników prac do zasobu stoi ustalenie niewystąpienia przesłanek z art. $12 \mathrm{~b}$ ust. 8 p.g.k. Wydanie decyzji o przyjęciu prac do zasobu również nie jest możliwe, jako że przyjęcie prac do zasobu następuje w formie czynności materialno-technicznej podjętej poza ramami postępowania administracyjnego.

Poddanie kontroli sądowej decyzji o odmowie przyjęcia wyników prac geodezyjnych do zasobu nasuwa pytanie o zakres tejże kontroli. Zgodnie z art. 134 $\S 1$ p.p.s.a. sąd rozstrzyga $w$ granicach danej sprawy, nie będąc jednak związany zarzutami i wnioskami skargi oraz powołaną podstawą prawną, z zastrzeżeniem

40 B. Adamiak, [w:] Metodyka pracy sędziego w sprawach administracyjnych, red. B. Adamiak, J. Borkowski, Warszawa 2020, s. 109.

${ }^{41}$ E. Śladkowska, Wydanie decyzji administracyjnej bez podstawy prawnej w ogólnym postępowaniu administracyjnym, ,Samorząd Terytorialny” 2005, nr 11, s. 46.

42 B. Adamiak, Weryfikacja..., s. 201-202.

43 Wyrok Naczelnego Sądu Administracyjnego oz. w Lublinie z dnia 20 czerwca 2002 r., II SA/Lu 507/02, LEX nr 738915.

44 B. Adamiak, Weryfikacja ..., s. 202-203. 
art. 57a. W wyroku z dnia 1 września 2017 roku Naczelny Sąd Administracyjny wskazał, że sąd administracyjny, kontrolując zgodność z prawem decyzji o odmowie przyjęcia wyników prac geodezyjnych do zasobu, uprawniony jest wyłącznie do oceny zaskarżonej decyzji w kontekście podstawy prawnej, na której została ona wydana. Sąd nie jest uprawniony do dokonywania samodzielnych ustaleń w zakresie prawidłowości sporządzenia dokumentacji geodezyjnej, której przyjęcia do zasobu odmówił organ administracji publicznej. Ocena tej dokumentacji należy do właściwych w sprawie organów administracji, sąd zaś może jedynie ocenić, czy ustalenia i działania organów nie naruszają obowiązującego prawa ${ }^{45}$. Pogląd ten uznać należy za uzasadniony.

Ocena rozwiązań normatywnych zadekretowanych w normach art. 12 b p.g.k. nie może być inna niż tylko krytyczna. Niejasność przepisów stwarza możliwość wielorakich sposobów ich interpretacji, co można zaobserwować, dokonując analizy orzecznictwa sądowego. Nowelizacje art. $12 \mathrm{~b}$ p.g.k. nie przyniosły zasadniczej poprawy w tym zakresie. Potęguje to stan niepewności odnośnie do własnej sytuacji prawnej pośród wykonawców prac geodezyjnych, co trudno uznać za akceptowalne w realiach demokratycznego państwa prawnego. Pozostają oni nieraz bezradni w procesie przyjęcia wyników ich prac do zasobu, mając świadomość, że skuteczność dochodzenia ich praw na drodze administracyjnej oraz sądowej pozostaje zależna od przyjętego sposobu wykładni prawa. Wydaje się, że wyjściem z zaistniałej sytuacji może być wyłącznie kolejna ingerencja prawodawcza.

\section{ACCEPTANCE AND REFUSAL OF THE RESULTS OF SUBMITTED GEODETIC WORKS INTO THE STATE GEODETIC AND CARTOGRAPHIC RESOURCES — SELECTED ISSUES}

\section{Summary}

Art. 12b of the Act of May 17, 1989 - Geodetic and Cartographic Law regulates the procedure of accepting the results of geodetic works into the state geodetic and cartographic resources. Its effect may be the acceptance of studies in the form of a material and technical activity or the refusal to accept the results of the work in the resource in the form of an administrative decision. Such a normative structure causes numerous problems in the practice of applying the law, related to, inter alia, with the admissibility of applying the provisions of the Code of Administrative Procedure, the initiation of administrative proceedings, the subject of the administrative case or the types of decisions of the appeal body. The author tries to answer the fundamental questions that the bodies of the Geodetic and Cartographic Service have to deal with on a daily basis.

Keywords: verification of geodetic or cartographic, documentation, verification protocol, administrative proceedings, material-technical activity, administrative decision

45 I OSK 2603/16, LEX nr 2394488. 


\section{BIBLIOGRAFIA}

Adamiak B., Czynności prawne jednostki a władztwo administracyjne, [w:] Wspótczesne zagadnienia prawa i procedury administracyjnej. Ksiega jubileuszowa dedykowana Prof. $z w . d r$. hab. Jackowi M. Langowi, red. J. Jagielski, E. Stefańska, M. Wierzbowski, A. Wiktorowska, Warszawa 2009.

Adamiak B., Pojęcie postępowania administracyjnego, [w:] Kodyfikacja postępowania administracyjnego: na 50-lecie K.P.A., red. J. Niczyporuk, Lublin 2010.

Adamiak B., Borkowski J., Glosa do wyroku Naczelnego Sądu Administracyjnego - Ośrodek Zamiejscowy we Wrocławiu z dnia 26 sierpnia 1988 r., sygn. akt $S A / W r 773 / 87$, „Orzecznictwo Sądów Polskich" 1990.

Adamiak B., Borkowski J., Kodeks postępowania administracyjnego. Komentarz, Warszawa 2017.

Adamiak B., Borkowski J., Metodyka pracy sędziego w sprawach administracyjnych, Warszawa 2020.

Adamiak B., Borkowski J., Postępowanie administracyjne i sądowoadministracyjne, Warszawa 2020.

Felcenloben D., Weryfikacja prac geodezyjnych i kartograficznych, „Samorząd Terytorialny” 2017, nr 1-2.

Krupiński J., Postepowanie w sprawie przyjęcia materiatów do powiatowej części państwowego zasobu geodezyjnego i kartograficznego, cz. III - podmioty postępowania, „Nieruchomości” 2018, $\mathrm{nr} 4$.

Lang J., Maćkowiak J., Myśliński T., Potrapeluk W., Stefańska E., Prawo geodezyjne i kartograficzne. Komentarz, Warszawa 2018.

System Prawa Administracyjnego Procesowego, t. 2, cz. 5. Weryfikacja rozstrzygnięć w postępowaniu administracyjnym ogólnym, red. B. Adamiak, Warszawa 2019.

Śladkowska E., Wydanie decyzji administracyjnej bez podstawy prawnej w ogólnym postępowaniu administracyjnym, „Samorząd Terytorialny” 2005, nr 11.

Wolanin M., Przyjmowanie opracowań do państwowego zasobu geodezyjnego i kartograficznego refleksje proceduralne, „Nieruchomości” 2017, cz. 2, nr 2. 